\title{
A Kierkegaardian Guide to Reading Scripture
}

\begin{abstract}
Kierkegaard is well known for being critical of a scholarly reading of the bible. It is generally understood that his primary concern was that "objective" biblical scholarship was undermining the possibility of a reader's subjective life being affected, challenged and provoked by its message. That is, it encourages an overly detached reading of Scripture that distracts persons from responding to its call to discipleship. It is indeed the case that Kierkegaard devoted himself to challenging the fact that the nominal Christians in Denmark were not actively responding Scripture. However, I shall argue that there is something much more fundamental to his critique of biblical scholarship. For Kierkegaard, the faithful reader is not primarily called to respond to the message of Scripture but to the living God who communicates to persons through Scripture. This paper will look at how Kierkegaard sought to remind Christians that Scripture is not an end in itself but a witness to the living God (who is the primary focus of the Christian life).
\end{abstract}

Søren Kierkegaard was a devoted reader of Scripture. ${ }^{1}$ As a Christian, he saw Scripture as a blessing that enabled him to know and follow the God he loved. For him, it was a witness designed by God to be a medium through which God could draw individuals to himself and inspire them to live out the lives for which they were created. However, for Kierkegaard, Scripture is also a blessing in disguise. That is, Scripture, "which can be seen," is a witness to "what is unseen"- to God. The problem with this, for him, is that Scripture's immediate appearance is able to fool readers into interpreting it primarily as a collection of poetry, stories, historical reports, and parables. That is, readers are able to neglect, forget, and pretend that it is not first and foremost a witness to God and God's relationship to the world. And, when this happens, Scripture can get in the way of the possibility of a loving relationship with God. When this happens, it can cease to be revelation and become a veil.

So why was this a concern for Kierkegaard? Kierkegaard was concerned about the way in which Christian scholarship in Denmark had happily devoted itself to a way of

\footnotetext{
${ }^{1}$ When discussing Kierkegaard's nervousness about certain approaches to biblical studies, it has become commonplace to cite the following sentence from Stages on Life's Way: 'The bible lies on my table at all times and is the book in which I read the most.' $S L W$, p. $230 / S K S$ 6, p. 214. While these words come from Kierkegaard's pseudonym Frater Taciturnus, I think that many of those who cite this passage are right to indicate that Kierkegaard probably would have been happy to own these words. See: Timothy Polk, "Kierkegaard's Use of the New Testament: Intratextuality, Indirect Communication, and Appropriation," in Kierkegaard and the Bible - Tome II: The New Testament, ed. Lee C. Barrett and Jon Stewart (Farnham: Ashgate, 2010), p. 237; Joel Rasmussen, "Kierkegaard's Biblical Hermeneutics: Imitation, Imaginative Freedom, and Paradoxical Fixation," in Kierkegaard and the Bible - Tome II: The New Testament, ed. Lee C. Barrett and Jon Stewart (Farnham: Ashgate, 2010), p. 249; Paul Martens, "Kierkegaard and the Bible," in The Oxford Handbook to Kierkegaard, ed. George Pattison and John Lippitt (Oxford: Oxford University Press, 2013), p. 153; Peder Jothens, Kierkegaard, Aesthetics, and Selfhood: The Art of Subjectivity (Farnham: Ashgate, 2014), p. 109.
} 
reading Scripture that was detached from the life of faith. This problem arose when Scripture came to be seen as an end in itself rather than a medium through which the Christian could come to know God and God's purposes for the world. While such an approach is perhaps understandable in the case of secular scholarship, Kierkegaard believed that such an approach was entirely inappropriate for the Christian scholar. For Kierkegaard, the Christian's whole life should be devoted to God; a relationship with God should be the absolute telos of the Christian life. Scripture, therefore, should not distract a person from this devotion. Rather, the Christian scholar should be expected to read Scripture faithfully, as a witness to the reality of the true God. ${ }^{2}$

This essay shall look at how Kierkegaard sought to remind Christians about what it means to interpret Scripture faithfully, as a witness to the living God. I shall begin by offering a brief account of the historical context that shaped Kierkegaard's thinking and concerns. I then go on to consider what he thinks we can learn from three characters in Scripture: Abraham, Job and the woman who was a sinner. What is significant about these figures, and what distinguishes them from the Christians of today (or Kierkegaard's day), is that they do not have the canon of scripture to get in the way of their relationship with God. There is, therefore, a sense in which these three figures exemplify a more direct orientation towards God. After considering what the theological interpreter might learn from these figures, I shall look at what Kierkegaard sees to be a way forward: to read Scripture as if it were a letter from a beloved. Finally, I end by offering a reflection on how Kierkegaard might respond to some challenges that could be directed at his hermeneutic. I conclude that while Kierkegaard's hermeneutic may have some weaknesses, it does offer a challenge to Christian interpreters of Scripture that is just as relevant today as it was in Kierkegaard's day.

\section{Historical Context}

To achieve a clear grasp of what was driving Kierkegaard, it is important to be aware of the particular context in which he was writing. It was in the midst of Danish Christendom that Kierkegaard had come to despair over Christian scholarship. In the wake of Hegel, Christian scholarship in Denmark had welcomed and, indeed, embraced a detached and critical

\footnotetext{
${ }^{2}$ Kierkegaard saw it as his life duty to 'express the truth, which I had daily perceived and ascertained-that there is a God.' Søren Kierkegaard, The Point of View for My Work as an Author, ed. and trans. Howard V. and Edna H. Hong (Princeton: Princeton University Press, 1998) (hereafter PV), p. 72 n. / Søren Kierkegaard Skrifter vol. 16, ed. Niels Jørgen Cappelørn, Joakim Garff, Kette Knudsen, Johnny Kondrup, Alastair McKinnon and Finn Hauberg Mortensen (Copenhagen: Gads Forlag, 1997-2013) (hereafter SKS), p. 51 n.
} 
understanding of the Bible. For Kierkegaard, this meant that Christian scholarship looked no different from secular scholarship. Christian intellectuals were seeking to make sure that their faithful lives did not interfere with their so-called "objective" understanding.

As such, Christian intellectuals were promoting a way of reading the Bible that held readers back from being affected, challenged, and provoked by its message - that held readers back from responding to Scripture's call to discipleship. Under these circumstances, Scripture was primarily being treated as a source of intellectual amusement. When this happened, the words of Scripture got in the way; they served to distract Christians from hearing and responding to Scripture with lives of faith. Against this approach, Kierkegaard insisted that there should be no division between a person's life of faith and her scholarship. So, when the Christian reads Scripture, there should be no difference between her faithful and her intellectual reading. For him, it is entirely disingenuous for the Christian to pretend that Scripture is not a witness to God in order to play the games of a secular world. The Christian life comes with a duty to serve as a continual witness to the truth that Christians has been given the eyes to see and the ears to hear.

It was this duty that was being ignored by the Christian scholarship of his day. As Kierkegaard watched on, scholars, who saw themselves as Christians, were diluting and sabotaging the integrity of Christianity — and this both tormented and sickened him. Indeed, at times, particularly towards the end of his life, this prompted him to become rather carried away in his critique. At one point, for example, he describes "assistant professors" as "those vermin who actually have demolished Christianity.' 3

This problem arises because, when a person studies Scripture, she becomes an observer of words and has a certain freedom to choose to interpret the significance of these words in a wide variety of ways. While the Christian believes that these words point both beyond themselves, and also beyond the context within which they were written and informed, this is not directly apparent. It is not immediately obvious that Scripture really is a witness to the reality of God. Furthermore, it is not at all obvious how it is a witness to the reality of God. This means that it is very easy for the Christian to end up doing two things.

First, it can be a temptation for the Christian to resort to reading Scripture with a

\footnotetext{
${ }^{3}$ Kierkegaard continues: 'those noble men who build the tombs of prophets, objectively recite their teaching, turn the suffering and death of the glorious ones into a profit - most likely objectively and most likely proud of the objective, since the subjective is sickliness, affectation - but keep themselves, naturally with the aid of the much-praised objectivity on the outside, far away from everything that even in the remotest manner could resemble suffering like the glorious ones.' Søren Kierkegaard, The Moment and Late Writings, ed. and trans. Howard V. and Edna H. Hong (Princeton: Princeton University Press, 1998) (hereafter M), pp. 340-3., p. 291 / SKS 13, pp. 348-49 (emboldening original).
} 
secular hermeneutic - with a methodological naturalism. By so doing, the Christian compartmentalizes between her faithful reading of Scripture and her academic reading: she can read Scripture one way in the academy, with her secular peers, and another way in the Church, with her Christian peers. It is not hard to see why a secular hermeneutic can seem more appropriate within the academy. It is because, for some, it can seem that anyone can read Scripture in this way: that is, as a library of historical documents to be questioned, ethical guides to be debated, and poetry to be interpreted freely according to the sentimentality of its reader.

Second, because of God's hiddenness, it can be very easy for the Christian to make Scripture the primary object of the Christian faith, rather than God. When this happens, Christians can find themselves worshipping what Scripture says, rather than viewing Scripture as a means of worshipping the God to whom Scripture witnesses. By focusing on the propositional statements of Scripture, a person can end up becoming distracted from the interpersonal (God-to-human, human-to-human, and, indeed, God-human-to-human) nature of the Christian faith.

In short, as a medium of communication, Scripture, on the one hand, is able to deliver a message. But, on the other hand, it is also able to get in the way of the messenger. Just like circumcision, the food laws, the miracles of Jesus, and the preaching of Paul, the Bible provides us with a sign that can end up obstructing an individual's faith or, indeed, the faith of a community. For Kierkegaard, the way in which Scripture was being read by Christian scholars in Denmark, was getting in the way of the Christian faith. It was against this backdrop that Kierkegaard sought to offer and encourage a faithful reading of Scripture, which sought to discern Scripture as a message from God. For Kierkegaard, the reality to whom Scripture witnesses is always greater, more interesting, more beautiful, and more true than that witness itself could ever be.

\section{How Do the "Truth-Witnesses" Relate to God?}

If it were the case that we had a more direct relationship to God or Jesus Christ, we would not be faced with this problem of Scripture getting in the way. For example, this problem was not one that was faced by many of the faithful characters who we read about in Scripturecharacters who seem to have a more direct relationship with God. For Kierkegaard, some of these characters serve as 'truth-witnesses' or 'derivative prototypes' (afledede Forbilleder) 
for Christians today. ${ }^{4}$ So, now, I want to consider what Kierkegaard thinks we might be able to learn from three of these figures: Abraham, Job, and the woman who was a sinner.

As these three figures find themselves caught up in the canon of Scripture, they call for our attention, not primarily because we should be interested in discovering more about who they are or where they are, but because, through them, we can hope to learn more about the God to whom these characters witness. So what can we learn from these prototypes?

\section{a. Abraham}

For Kierkegaard, Abraham is 'an eternal prototype of the religious person. ${ }^{5}$ In a journal entry, he writes:

...just as Abraham had to leave the land of his forefathers for a foreign land, so indeed must the religious person leave, i.e., forsake, an entire generation of his contemporaries - even though he remains among them, albeit isolated, alien to them. Being an alien, being in exile-this is precisely the characteristic suffering of the religious person.' 6

In Abraham, Kierkegaard saw someone who was willing to respond to God by doing something (sacrificing his son) that is incomprehensible and offensive to those who do not have Abraham's faith. As such, his faith isolated him from the ways of the world.

The reason that Abraham was willing to respond to God's call was because his faithful perception of reality taught him that God is the ultimate truth that gives truth to the world. Furthermore, Abraham saw his relationship with God as the absolute telos of his existence, and, therefore, the telos that guided his every decision. In these respects, Abraham expressed himself in a way that is prototypical of what it means to have faith in God. When we read about Abraham, it can seem as though he had a kind of direct connection with God. It is hard to imagine that Abraham would have shown the same willingness to respond to the call to sacrifice Isaac if he had learnt about this calling indirectly, from the pages of a book.

From Abraham, Kierkegaard learns that the genuine Christian scholar will find that

\footnotetext{
${ }^{4}$ M, p. 291 / SKS 13, pp. 349. For Kierkegaard, the primary prototype for the Christian life is Jesus Christ.

${ }^{5}$ Kierkegaard, Kierkegaard's Journals and Notebooks, vol. 7, ed. by Niels Jørgen Cappelørn, Alastair Hannay, David Kangas, Bruce H. Kirmmse, George Pattison, Vanessa Rumble, and K. Brian Söderquist (Princeton: Princeton University Press, 2014) (hereafter $K J N)$, p. 300 / SKS 23, p. 295 [NB18:64].

${ }^{6} K J N$ 7, p. 300 / SKS 23, p. 295 [NB18:64].
} 
her faithful and personal relationship with God will isolate her and alienate her from her secular peers. By standing firm as a truth-witness, it will be almost inevitable that the Christian scholar will find herself exiled by those academics who interpret reality with a secular mind. But, for Kierkegaard, the Christian scholar should never cease to interpret reality in a way that corresponds to her relationship with God. Any form of methodological naturalism is not an option for the Christian scholar; the Christian cannot compromise her faith. Why is this the case? This is because the Christian scholar has devoted her life to the one truth who lies beyond the words of Scripture. Her relationship with God is the absolute telos of her religious life. Accordingly, the Christian cannot but read Scripture in a way that is faithful to the God she loves-even if this entails sacrificing her credibility in the eyes of her secular colleagues.

\section{b. Job}

Like Abraham, Kierkegaard viewed Job as 'a prototype for the human race. ${ }^{7}$ What made Job exemplary was not 'what he said but... what he did. ${ }^{8}$ Accordingly, for Kierkegaard, the faithful reader of Job should not 'devote [herself] to think[ing] about what [Job] said but to following what he did. ${ }^{9}$

So, what do the actions of this tragic figure teach us? Job lived out his theological teaching in response to God. His life embodied the words, "the Lord gave, and the Lord took away; blessed be the name of the Lord." ${ }^{10}$ In Kierkegaard's terms, Job repeated these words in his existence.

For Kierkegaard, a person has not understood the Christian message, in truth, if it does not transform her life. If Job had studied, contemplated, and speculated over these words - if he had written books on these words - but had not lived them out, before God, then Job would not have truly understood what he was saying. The truth of Christianity is known in and through a life of faith; God communicates himself to a person's entire existence, inspiring her to live out the Christian message that she receives. Any failure to respond to this message holistically points to a failure on the part of that person to understand the Christian message. So, like Job, the faithful scholar does not only teach people about

\footnotetext{
${ }^{7}$ Søren Kierkegaard, Upbuilding Discourses in Various Spirits, ed. and trans. Howard V. Hong and Edna H. Hong (Princeton: Princeton University Press, 1993), p. 284 / SKS 8, p. 379.

${ }^{8}$ Søren Kierkegaard, Eighteen Upbuilding Discourses, trans. Howard V. Hong and Edna Hong (Princeton: Princeton University Press, 1990) (hereafter EUD), p. 109 / SKS 5, p. 117.

${ }^{9}$ EUD, p. 109 / SKS 5, p. 117.

${ }^{10}$ EUD, p. 109 / SKS 5, p. 117.
} 
Christianity with spoken teaching or written word, but also with a life of witness. The fact that Job's teaching is not only known in his mind but is also known (lived out) in his existence is the reason that Kierkegaard views Job as a prototype for humanity. Job demonstrates what it means to be a faithful intellectual.

In short, Job's teaching was taken up into his life in a way that expressed a deep and holistic understanding of his relationship to God. Far from "objectively" distancing Job from God, Job's teaching corresponded to his life of relationship with God, articulating what it means to struggle in times of trial. As such, his teaching was embraced as a guide that taught him what it means to exist faithfully before God.

For Kierkegaard, the Christian scholar who seeks to make sense of Scripture but does not respond to Scripture holistically (intellectually, personally, and existentially), has not made sense of Scripture. To interpret Scripture in truth, the Christian must interpret it before God as a message from God. When a Christian approaches Scripture in this way, her understanding of it will be evident in the way that it transforms her life. Her existence will be a repetition of what she learns from its pages.

\section{c. The Woman Who was a Sinner}

Finally, what about the woman who was a sinner? Kierkegaard reflects on this woman in a discourse that focuses on Luke 7.36-50, in which a sinful woman comes to sit at Jesus's feet and, as she weeps, bathes Jesus' feet with her tears and dries them with her hair (Luke 7.38).

In this encounter, for Kierkegaard, the woman expresses: 'I am capable of literally nothing; he is capable of unconditionally everything. ${ }^{11}$ When she weeps at the feet of Jesus, 'she has forgotten herself completely. ${ }^{12}$ And she forgets herself, not by looking to herself, to try to silence her sinfulness, but by losing herself in the presence of her saviour. In this encounter, the woman 'is calmed like the sick baby that is calmed at its mother's breast, where it cries out and forgets itself., ${ }^{13}$ When she weeps, she weeps with 'blessed tears of selfforgetfulness' that do 'not remind her anymore of what she is weeping over' but express the fact that 'she has forgotten herself completely.' 14

\footnotetext{
${ }^{11}$ Søren Kierkegaard, Without Authority, trans. Howard V. and Edna H. Hong (Princeton: Princeton University Press, 1997) (hereafter WA), pp. 139-40 / SKS 11, p. 276.

${ }^{12}$ WA, p. 140 / SKS 11, p. 276.

${ }^{13}$ WA, p. $140 /$ SKS 11, p. 276.

${ }^{14}$ WA, p. 140 / SKS 11, p. 276.
} 
For Kierkegaard, to 'forget oneself completely' is 'the true expression of loving much. ${ }^{15}$ The reason for this is that when a person loves much, she loses herself in her devotion to another; the self that a person brings to a relationship becomes irrelevant in her loving preoccupation with the other. In this case, the woman becomes 'lost in her Savior' and, in doing so, finds forgiveness of sins. ${ }^{16}$ In her encounter with Jesus Christ, she becomes a new person. As Carl Hughes puts it: 'She becomes the picture that Christ makes of her.'17

It is hard to imagine this scene unfolding in the way that it did had the woman not directly encountered Jesus but had simply read about him in Scripture. Why? This is because it is difficult to conceive of her being as captivated by words of a text as she was by her direct encounter with Jesus Christ. Had she simply read about him, about forgiveness, and about reconciliation, from the pages of a book it seems unlikely that it would have provoked the same response. The reason for this is that a relationship mediated through the pages of a book appears less personal than a relationship that arises through a direct encounter(s). So, here again, it is easy see how Scripture could have gotten in the way. Clearly, it is not possible today for a person to have a direct encounter with Jesus Christ directly in the same way as the woman Luke describes. ${ }^{18}$ Yet, for Kierkegaard, it is still possible to encounter the presence of the risen and ascended Jesus Christ. ${ }^{19}$ For him, it is indeed possible for a person to encounter Jesus Christ through reading Scripture and thereby find herself being transformed in and through the process of reading the text. However, for Kierkegaard, precisely such possibility is undermined by a detached reading of Scripture.

For Kierkegaard, it as an 'unfortunate confusion' when, on a scholarly reading of the New Testament, people are led to 'think that God is far away, that it is 1800 years since [Christ] died. ${ }^{20}$ Scripture is to be read as a message from the living God who continues to speak to its faithful readers. It should not be read merely as a record of God's love but as a living testimony to the loving God who continues to be present alongside us. So, we should be approaching Scripture in a way that is comparable to the way in which the sinful woman approached Jesus. We should come to Scripture with a desire to know and discover the news

\footnotetext{
${ }^{15} W A$, p. $140 / S K S 11$, p. 277.

${ }^{16}$ WA, p. $141 /$ SKS 11, p. 277.

${ }^{17}$ Carl Hughes, Kierkegaard and the Staging of Desire: Rhetoric and Performance in a Theology of Eros (New York: Fordham University Press, 2014), p. 127.

18 That said, Kierkegaard later remarks that 'we have one comfort that she did not have': that Christ has died to save us, to bring about atonement 'that makes doubting of the forgiveness of sins impossible' for the person of faith. WA, pp. 158-59 / SKS 11, pp. 271-72.

${ }^{19}$ Søren Kierkegaard, Christian Discourses, ed. and trans. Howard V. and Edna H. Hong (Princeton: Princeton University Press, 1997) (hereafter CD), p. 261 / SKS 10, p. 274.

${ }^{20} K J N$ 5, pp. 338-39 / SKS 21, p. 328 [NB10:140].
} 
of our forgiveness, our redemption, and the news of God's love. By so doing, a person is much more likely to become captivated by Scripture's witness to God.

Again, to read Scripture faithfully and truthfully involves a holistic process of becoming. Also, if this becoming is to be truly Christian, it will be the consequence of a person's being transformed in and through encountering the presence of God's love in Jesus Christ: the love that uniquely draws readers to live lives of love. For Kierkegaard, the woman in Luke is a prototype, insofar as she becomes 'lost in her Saviour.' ${ }^{21}$ She finds her speech, her language, the restlessness of her thoughts stilled and transformed by the presence of Jesus Christ.

I might also add that, for Kierkegaard, the woman who was a sinner was mocked and judged by the Pharisees, as she sat at the feet of Jesus, anointing his feet with ointment. ${ }^{22}$ Moreover, as Jesus recognized her and became involved with her, the Pharisees condemned not only her but also Jesus - they took offense at Jesus. According to the teaching of the Pharisees, this was not the way things are done in the world. But, for Kierkegaard, the love of this prototype for Jesus Christ silenced the surrounding noise and humiliation, which may have prompted her to act otherwise.

\section{Reading Scripture as a Letter from a Beloved}

Foundational, therefore, to a Christian reading of Scripture, for Kierkegaard, is a loving devotion to God - as the one to whom Scripture witnesses. This is particularly evident in his well known belief that Scripture is to be read 'in the same way' as one would read a letter from a beloved. ${ }^{23}$ As Kierkegaard advises, the Christian should give herself time to be 'alone with God's Word' and should occupy herself with her relation to God. ${ }^{24}$ She must 'not concern [her]self objectively with the letter from the beloved.' ${ }^{25}$ That is, she must not primarily concern herself with a speculative analysis of the biblical texts (the letter), but with hearing the personal message that God (the beloved) speaks to her through Scripture.

As David Cain notes on Kierkegaard, 'how one reads is decisive in determining what

\footnotetext{
${ }^{21} W A$, p. 141/ SKS 11, p. 277.

${ }^{22} W A$, p. 141/ SKS 11, p. 277.

${ }^{23}$ Søren Kierkegaard, For Self-Examination, ed. and trans. Howard V. and Edna H. Hong (Princeton: Princeton University Press, 1990) (hereafter FSE), p. 26 / SKS 13, p. 54.

${ }^{24}$ FSE, p. 32 / SKS 13, pp. 58-59. Scripture is to be read, as Paul Martens aptly notes, like 'a letter that-much like the way that Jesus taught the disciples to pray (Matt 6:7) — is read in private, behind locked doors.' Martens, "Kierkegaard and the Bible," p. 158.

${ }^{25} K J N 7$, pp. $153-54$ n. a / SKS 23, p. 151 [NB16:84a].
} 
one reads. ${ }^{26}$ So, how one reads Scripture will be decisive for determining whether or not Scripture will be the kind of book that gets in the way of a person's Christian faith. And, for Kierkegaard, what the Christian is supposed to be reading is the word of God, something that historical-scientific scholarship is not in a position to discover. ${ }^{27}$ The 'historical-critical method,' as Murray Rae notes, 'harbours prejudicial assumptions which are critically determinative of the results it achieves. ${ }^{28}$ For Kierkegaard, these prejudicial assumptions critically determine that a person does not read the Bible as God's word. To read God's Word, a person must view Scripture as the object of faith (Troens Gjenstand) and must read it with the eyes of faith (Troens Øie). ${ }^{29}$ By so doing, she can come to read Scripture as an 'individual who has received this letter by God or from God. ${ }^{30}$ That is, she can come to read it earnestly, as a love letter through which God speaks to her. ${ }^{31}$

To read Scripture in this way, Kierkegaard proposes, a person must read it 'without a commentary'; indeed, he goes so far as to describe this as the 'Principal Rule. ${ }^{32}$ Like so many of Kierkegaard's more vehement statements, this comment needs to be taken cum grano salis, keeping in mind his particular concerns. Richard Bauckham puts it well when he notes: 'Kierkegaard's attitude to biblical scholarship is a necessary over-reaction, necessary as a corrective but an overreaction all the same. ${ }^{33}$ Kierkegaard's concern here is that commentaries were encouraging an objective reading of the Bible that focused on the intellectual question, "What precisely is the meaning and context of this biblical passage?," in a way that disregards the existential and personal question, "What is God saying to and asking of me through and by means of the scriptural passage?."34

Kierkegaard observed that, under the pressure of scholarly doubt, Christians in Denmark were studying God's message without appropriating this message to their daily lives. For him, this pointed to the fact that 'they seem completely to forget that God still

\footnotetext{
${ }^{26}$ David Cain, “Death Comes in Between': Reflections on Kierkegaard's For Self-Examination," in Kierkegaardiana 15 (1991), p 71.

${ }^{27}$ FSE, p. 33 / SKS 13, p. 60.

${ }^{28}$ Rae, Kierkegaard's Vision of the Incarnation: By Faith Transformed (Oxford: Oxford University Press, 1997), p. 185.

${ }^{29}$ Søren Kierkegaard, Journals and Papers, vol. 4, ed. and trans. Howard V. and Edna H. Hong (Bloomington: Indiana University Press, 1967-78) (hereafter JP), 3916 / SKS 27, p. 303 [Papir 306].

${ }^{30} K J N$ 7, pp. 450-51 / SKS 23, p. 442 [NB20:88].

${ }^{31}$ FSE, p. 36 / SKS 13, pp. 62-63.

${ }^{32} K J N$ 7, p. 153 / SKS 23, p. 151 [NB16:84] (emphasis original). Kierkegaard says this with regard to the New Testament. However, it is fair to assume that he would also see this rule to apply to a person's reading of the Old Testament.

${ }^{33}$ Richard Bauckham, James: Wisdom of James, Disciple of Jesus the Sage (London and New York: Routledge, 1999), p. 8.

${ }^{34}$ See $K J N 7$, pp. 153-54 / SKS 23, p. 151 [NB16:84]
} 
exists [er til]. ${ }^{35}$ That is, Christians had become so caught up with examining the letter that they had forgotten about the one who sent the letter. In particular, they were acting as though there was no God addressing them through the words of Scripture, calling them to faith and action. The scholarship that so-called "orthodoxy" was pursuing, Kierkegaard observes, 'makes God's Word into something impersonal, objective, a doctrine-instead of its being the voice of God that you shall hear.' ${ }^{36}$ As such, he describes 'Christian scholarship' as 'the human race's enormous invention in order to protect itself against the N.T., in order to ensure that a person can continue to be a Christian without the N.T. getting altogether too close to him.' ${ }^{37}$ By keeping themselves removed from Scripture, scholars were undermining the possibility of being transformed in response to its message. Such detachment stops readers from allowing God's word to speak into their lives, to inspire repentance and discipleship.

On Kierkegaard's account, therefore, to know the true meaning of Scripture, a person must be given to relate to it faithfully. This requires a person to devote herself passionately to Scripture in response to the love of God. By so doing, she will come to engage with Scripture with a new mind: she will come to relate to Scripture by way of 'a leap, whereby I break the chain of reasoning and define a qualitative newness.' ${ }^{38}$ In this respect, Kierkegaard's hermeneutic very much finds itself in alignment with the Anselmian principle of faith seeking understanding; although it might perhaps be better associated with a love seeking understanding. What this suggests is that the task of Christian scholarship should always be to facilitate and complement all that is involved in a reception of Scripture that can genuinely be said to be faithful. ${ }^{39}$

\footnotetext{
${ }^{35} J P$ 1, 214 / SKS 24, p. 445 [NB25:11].

${ }^{36}$ FSE, p. 39 / SKS 13, p. 65.

${ }^{37} K J N$ 7, p. 245 / SKS 23, p. 241 [NB17:102].

${ }^{38}$ KJN 6, P. 36 / SKS 22. p. 40 [NB11:63].

${ }^{39}$ At this point, it should be made clear that Kierkegaard does not altogether neglect the fact that scholarship is needed to assist a faithful reading of Scripture. The Bible needs to be translated and, at times, carefully interpreted - as is evident in Kierkegaard's own careful engagement with Scripture. (Kierkegaard makes sure to mention that he does not set out to 'disparage scholarship' per se-'no, far from it.' Rather, he sought to challenge scholars to remember that 'when you are reading God's Word in a scholarly way, with a dictionary etc., then you are not reading God's Word.' FSE, pp. 28-29 / SKS 13, p. 56.) However, drawing on the metaphor of Scripture as a love letter that needs to be translated, Kierkegaard notes that once a person 'is finished with the translation,' 'he reads his beloved's letter.' FSE, p. 27 / SKS 13, p. 55. Indeed, he goes so far as to describe the 'scholarly preliminaries' as a 'necessary evil' that are required as a means of bringing a person to the point where he can read 'the letter from his beloved.' FSE, pp. 27-28 / SKS 13, pp. 55-56. The problem with the scholarly preliminaries is that they stall the process of Christian becoming by taking time - time that could be spent hearing and actively responding to the message. As such, for Kierkegaard, when the Christian spends time on the scholarly preliminaries, she should feel an urgency to get through this process quickly so that she can get on to responding to Scripture. The Christian should feel the kind of urgency that a lover would feel if she were to receive a love letter from a beloved that was in need of translation. As soon as she has heard the message, the Christian should be off at once to fulfil his beloved's wish. KJN 5, pp. 338-39/ SKS 21, p. 328 [NB10:140].
} 


\section{Concluding Remarks}

If Kierkegaard's understanding of Christian hermeneutics is to be a constructive contribution to theological interpretation, there are a number of questions that need to be addressed. Does Kierkegaard's hermeneutic end up attaching too much authority to the particular faith of the Christian? Is Kierkegaard in danger of allowing the Christian, as Joel Rasmussen points out, 'to appropriate the Bible in just about any fashion one likes'? ${ }^{40}$ Also, does Kierkegaard's hermeneutic risk sliding into a kind of uncritical pietism that sidesteps the question of Scripture's origins? If Scripture provides an account of God revealing himself in history, is there not a place for Christians devoting their lives to scrutinizing the Scriptural texts, with a historically critical mindset? Is there no possibility that one might do this in the service of the Church?

These are all important questions that Kierkegaard's hermeneutic needs to address. And there is no shortage of passages in his writings that beg these questions. Again, however, such passages need to be taken cum grano salis, with an awareness of his contextual concerns. Also, they need to be read with a hesitancy to take 'Kierkegaard's polemical extravagance' at face value. ${ }^{41}$ There is no doubt that Kierkegaard's rhetorical edge does not always help his cause.

So, in what way might Kierkegaard be able to address these questions? The first thing to mention is that, for Kierkegaard, the major problem facing Christianity in Denmark was not that too many people were misinterpreting the Bible. The problem was not that the Bible was too difficult to understand. Rather, the problem was that "Christians" were not responding to the straightforward messages of Scripture. Instead, they were devoting the majority of their time to studying and contemplating the (less essential) complexities of Scripture. What made this situation worse was that "Christian" scholars-who were supposed to be reading Scripture faithfully-were perpetuating the problem. They were devoting themselves to pondering the obscurities of Scripture and failing to be shaped by the passages that were so easy to understand. Caricaturing such scholars, Kierkegaard notes that they show their

\footnotetext{
${ }^{40}$ Joel Rasmussen, "Kierkegaard's Biblical Hermeneutics," p. 262. Rasmussen continues: 'then we might also wonder whether there is any point to talking hermeneutics at all (where the goal is to arrive at the most fitting interpretation - one where it makes sense to say interpretation $\mathrm{X}$ is better than $\mathrm{Y}$ ), and say instead that "interpretation" is nothing but free and imaginative play and deferral.' p. 262.

${ }^{41}$ John Elrod, Kierkegaard and Christendom (Princeton: Princeton University Press, 1981), p. 97. Kierkegaard frequently makes overstatements that are meant to provoke the reader to ask more about the point he is trying to make. As such, the reader of Kierkegaard should be careful to read too much into such statements as they immediately appear.
} 
admiration for the New Testament by attempting to 'flatter' it; they describe it as 'so wonderfully delightful, so unfathomably sublime, etc.. ${ }^{42}$ For Kierkegaard, this constituted a form of procrastination. Scholarship was distracting people from taking the decisive steps forward in discipleship - steps that were necessary for the process of becoming Christian. Under these circumstances, 'we human beings, we are really rather cunning rogues': 'we pretend that we cannot understand it [the New Testament] because we understand very well that if it could be understood immediately, we would immediately have to act in conformity with it. ${ }^{43}$

In response to this dynamic, Kierkegaard saw it as a part of his Christian duty to help people recognize and admit the extent to which the New Testament is easy to understand. ${ }^{44}$ The complexity of the New Testament does not provide an adequate excuse for Christians to fail to respond to its call. As Bauckham notes, there 'are enough perfectly clear ones [biblical texts] to keep one busy without having to wait for the conclusions of biblical research before one can live as a Christian. ${ }^{45}$ Kierkegaard asks with rhetorical bite,

Put the New Testament in front of you. Read it. Can you deny, dare you deny, that what you read in it about renouncing everything, giving up the world and being mocked and spat upon like your Lord and Master, can you deny, dare you deny, that it is so easy to understand, indescribably easy, that you do not need a lexicon or handbooks or anybody else's help in order to understand it? ${ }^{46}$

For Kierkegaard, the general perspicuity of the New Testament should be sufficient to stop faithful readers of Scripture from having too much poetic license. As such, he did not think it was too risky to insist upon a faithful and personal reading of Scripture. For the Christian in Denmark, equipped with a Danish translation of the Bible, there was so much that was easy to understand. Again, the problem was that Scripture was not inspiring faithful action. So, for him, the question that Danish Christians needed to start asking themselves was not, "What can I learn from a systematic reading of Scripture?," but rather "How can I follow God's word?."

\footnotetext{
${ }^{42} K J N$ 7, p. 245 / SKS 23, p. 242 [NB17:102].

${ }^{43} K J N$ 7, p. 245 / SKS 23, p. 242 [NB17:102].

${ }^{44} K J N$ 7, p. 245 / SKS 23, p. 242 [NB17:102].

${ }^{45}$ Bauckham, James, p. 7. Bauckham's commentary on James is one of the few pieces of biblical scholarship to take Kierkegaard seriously. In this work, he includes quotations from Kierkegaard in the opening to each of his chapters. Also, he starts his study with an entire prologue acknowledging Kierkegaard's critique of biblical scholarship - a critique that he sees as being just as relevant today.

${ }^{46}$ KJN 5, p. 338 / SKS 21, p. 327 [NB10:140].
} 
Kierkegaard was concerned about waking Christians up to leave their nets, to take up their crosses, and follow Jesus. Kierkegaard wanted the self-proclaiming "Christian" readers of the Bible to feel a sense of urgency to "Go and do likewise" (Lk. 10.37). ${ }^{47}$

While Kierkegaard asserts that Scripture gives the faithful reader clear guidance on matters of Christian discipleship, he was also very aware that there are crucial elements to Scripture's message that are profoundly complex and scandalous to human reason. Aside from the scandal of the incarnation, Kierkegaard also acknowledges that there are inconsistencies and discrepancies in the Bible. Indeed, at one point Kierkegaard notes in a journal entry, entitled 'A New Proof of Bible's Divinity': 'Precisely because God wants Holy Scripture to be the object of faith and an offense to any other way of looking at it, it is precisely for that reason that these discrepancies have been carefully contrived (which will in any case be resolved into agreements in eternity): that is why it is in bad Greek, etc., etc. ${ }^{48}$ So, despite Kierkegaard's insistence on the perspicuity of Scripture, he was also clear that Scripture will leave even the most faithful of readers with a radical sense of uncertainty.

Such uncertainty, however, does not, in and of itself, call the reader into further study. While this might be beneficial eventually, Kierkegaard thinks that such uncertainty should first prompt the faithful reader to turn to God for counsel. And this may well lead her to decide that such uncertainty is not in need of explanation. Why? The is because the goal of the Christian faith is not a systematic understanding of the Bible - indeed, such pursuits can end up being unfaithful to God. Rather, the goal of the Christian life is right relationship with God, and the Christian should be well aware that life in this relationship will require her to embrace radical uncertainty. It is within this uncertain relationship that she becomes impassioned to hear God's word and respond with an active life of obedience. As such, the faithful reader will not find her faith in God called into question when she comes across (apparent) discrepancies or contradictions in the Bible. Why not? This is because the Christian's direct relationship to the Bible is incommensurate with and secondary to her love of God.

The problem, however, is that so often, when the uncertainty of the Bible is seen to be an obstacle for the Christian, she will turn first to the powers of systematic investigation to help her uncover the truth of Christianity in Scripture. Under these circumstances, it becomes

\footnotetext{
${ }^{47}$ FSE, p. 41 / SKS 13, p. 61.

${ }^{48} K J N$ 7, p. 440 / SKS 23, p. 432 [NB20:70]; see also JP 4, 3860 / SKS 24, pp. 148-49 [NB22:86]. Kyle Roberts helpfully clarifies Kierkegaard's point here, writing: 'It seems odd to speak of God "intending" imperfections in Scripture; Kierkegaard's point is that God's provision of revelation did not necessitate the circumvention of the ambiguities of finitude.' Kyle Roberts, Emerging Prophet: Kierkegaard and the Postmodern People of God (Eugene: Cascade, 2013), p. 24 n. 46.
} 
the speculative dogmatician, with the most systematic reading of Scripture, who can claim to have best accessed the truth of Christianity. In reaction to this modernist hermeneutic, Hugh Pyper rightly notes, Kierkegaard continually sought 'to recover the sense of the Bible as scandal. ${ }^{49}$ Pyper continues: 'The very fact that its contents are disputed and disrupted is to him [Kierkegaard] paradoxically part of its power.' ${ }^{50}$ Reading Scripture faithfully, for Kierkegaard, calls into question the minds, the beliefs, and the pride of its readers. It exposes the inadequacy of their possessive pursuit of understanding. And, by so doing, it generates 'the scandal of uncertainty which,' Pyper notes, 'is the condition of faith.' ${ }^{51}$ Why is it the condition of faith? Because this uncertainty calls readers to turn away from themselves--away from their own reason - and turn prayerfully toward God to enable them to know God in truth.

So, for Kierkegaard, the Bible should be read with humility - a willingness 'to comprehend that one cannot comprehend it. ${ }^{52}$ This does not mean that one should read Scripture with a fideism that is blind to its discrepancies. Rather, Scripture is to be embraced in all its offensiveness, as something that does not bend to the wiles of modern systematic reading. The faithful interpreter of Scripture is called to engage with the Bible in a way that is true to its nature. She is called to read Scripture as a witness to the living God, as a letter through which God speaks to her, transforms her and draws her to himself. Accordingly, Scripture is to be read prayerfully, with a readiness to turn to God for understanding.

O God, you give your Word as a gift - that you do, Infinitely Sublime One, and we human beings have nothing to give in return. And if you find only some willingness in the single individual, you are promptly at hand and are, first of all, the one who with more than human - indeed, with divine, patience sits and spells out the Word with the single individual so that he may understand it aright; and then you are the one who, again with more than human - indeed, with divine - patience takes him by the hand, as it were, and helps him when he strives to act according to it - you, our Father in heaven. ${ }^{53}$

\footnotetext{
${ }^{49}$ Hugh Pyper, The Joy of Kierkegaard: Essays on Kierkegaard as a Biblical Reader (Oakville: Equinox Publishing 2011), p. 22.

${ }^{50}$ Pyper, The Joy of Kierkegaard, p. 22.

${ }^{51}$ Pyper, The Joy of Kierkegaard, p. 50.

${ }^{52} K J N 5$, p. 70 / SKS 21, p. 68 [NB6:93].

${ }^{53}$ FSE, p. 14 / SKS 13, p. 44.
} 


\section{Conclusion}

It would be fair to critique Kierkegaard for being unable to offer a complete response to the questions raised in the final section of this essay. It would also be fair to critique him for overstating his case, at times. However, it is hard to deny that Kierkegaard's position offers a challenge that is every bit as relevant today as it was in his own time. For those who are Christian scholars, Kierkegaard calls them to ask themselves a question that should be fundamental to their very existence: does my scholarship serve my primary vocation —namely, to love, hallow, and obey God with all my heart and soul and mind? If it is the case that God's self-disclosure includes the faithful witness of Biblical writers bearing faithful testimony to it, then the Christian needs to ask herself: does my scholarship meet the conditions for the possibility of its being a faithful witness to this reality? 